\title{
Role of Optimism over Pessimism in the Novels of Thomas Hardy: Mechanism of Chance and Fate
}

\author{
Manoj Kumar Yadav \\ Associate Professor of English, \\ Lalawali (Bansur) Alwar, Rajasthan, India- 301402 \\ kkudrmanoj@gmail.com \\ Meenakshi Sharma Yadav \\ Assistant Professor of English, \\ King Khalid University, Abha, Saudi Arabia, Postal Code- 61421 \\ kkudrmeenakshi@gmail.com, m-@kku.edu.sa
}

DOI: https://doi.org/10.36892/ijlls.v2i1.115

\begin{tabular}{ll} 
Received: & Abstract \\
20/12/2019 & Thomas Hardy is mostly acclaimed as a pessimist novelist whose plots are full \\
of tearful tragic tales. In all his novels, the adverse situations come from the \\
Accepted: & uncertain conditions of the role of the chance that emerges based on the \\
characters'psycho-analytic states and eccentric impulses, financial variations & and barriers, irregularities of social status and standards, communal, cultural \\
& and ethnic misunderstanding, lack of trust in the marital relationship, thrust \\
\hline Keywords: & and lust of sexual pleasure, historical attitudes and backgrounds, highness of \\
Accidentalism; & royal families, and religion egoism on the unmatched unities of action, place, \\
Geopolitical; & and time in the Victorian modernity that forces all the characters to survive a \\
Feeling Brain; & life full of sufferings and misfortunes throughout the plots. But this paper has \\
Thinking Brain; & a fresh approach to explore the philosophy of optimism in Hardy's novels that \\
Calvinism; & how the male and female characters, despite facing the irony of fate and \\
Wessex; & chance, have a shining line of hope, faith and love in their lives. He accepted \\
Meliorist; & the fact that humanity goes forward from darkness to light, from despair to \\
Optimistic Psyches & hope and from pessimism to optimism. He was endowed with optimism as he \\
always hoped for advancement and betterment in every sphere of life. He & valued certain outstanding basic values like hope, love, affection, sympathy, \\
kindness, gentility, and selflessness. A humble effort has been made in the \\
present paper to trace out these 'good things in the bad things' in the novels \\
of Thomas Hardy. Hence, it can be seen that Hardy has been proved as the \\
surveyor of human spectrum in all its aspects, at times striking a note of \\
discord, but on the whole presenting a case of doing the mechanism of \\
accidentalism for the robust optimism over pessimism in his novels.
\end{tabular}

\section{INTRODUCTION}

Undoubtedly, Thomas Hardy's (1840-1928) reputation rests among the most wellknown novelists, poets, and short storywriters of the Victorian era, but firstly, he is a pioneer and prominent British regional novelist of Wessex that is a southwestern located England region where he himself grew up in the county of Dorset. The literary realism of Wessex represents reality and naturalistic aspects of the portraying mundane, everyday experiences, as his characters are nipped into the local real life. It depicts familiar people, places, stories, and primarily actions and times about the middle and lower classes of the society. Local community, color, creed, culture and ethnic attitudes are focused on the characters, dialects, 
customs, geography, architecture and other features are depicted and decorated particularly to a specific region, Wessex, in all his novels.

With a close reading of Hardy's major fiction, we came to know that his plots were commonly followed to put side by side a series of accidental events of chance, mishap, and irony of fate which appear suddenly, coincidently, and untimely that play a critical and terrible role to change a man's destiny in his novels. This process of tragic impulses punishes determinedly all his characters to a bit better or worst conditions throughout in his novels. This procedure is a kind of accidents that appear and follow constantly from rising action to denouement in the plot. As Hardy once said, "Pessimism is, in brief, playing the sure game. You cannot lose at it; you may gain. It is the only view of life in which you can never be disappointed". Therefore, this mechanism of accidentalism determines to survive a rigid and futile life that has no pity for the characters' suffering. Hardy's philosophy of plots is a study of ancient tragedy that gave emergence to the notions of chance and time, circumstances, fate, nature, providence, nemesis and will tinctured with metaphysical idealism. This philosophy plays the vital roles of the real life to develop the opinion of various philosophical and ethical perspectives in the characterizations.

\section{RESEARCH METHODOLOGY}

The descriptive and qualitative research methodology has been applied in this research paper. This methodology explores the results of the scientific discussion and the factual discourse analysis for the new useful information through the objectives, experiments, observations, comparisons, reasoning, and systematic analysis of an endless scientific experiment. The ground theory of this methodology investigates the objectives of the comparative research problems which are being stated about an acute observation of the late Victorian industrial ethnographic movement era. The social irregularities were the marital strict laws and divorce, discrimination in social laws, religious and political development, struggle for the better relationship, adverse financial clouds, and scarcity of the occupation so on. Hardy's novels show clearly the notable cynical and critical struggles among the characters to sustain their relations with other characters which fall finally due to wild impulses, misogynistic feelings, and opulent efforts for the fake freedom in the community and society during the Victorian era. The characters struggle psychoanalytically throughout the plots which come over the conspiracy that pushes them forcefully to survive an accidental life of chance and mishaps. Furthermore, here, the geopolitical theory also focuses truly on adverse and terrible conditions of the adaption and relationship around the geography of the local regions and its phenomena in the Wessex province. That, where and how did the characters take birth? What were their ethnic and cohesive identities? What were their heredity adoption and social treatment and behavior? What and where their occupations were located around the Wessex province. All there were emerging elements and issues had the challenging and unanswered questions during the Victorian era. But Hardy criticized appropriately these questions and social problems with the optimistic notes over pessimistic flow in the both male and female characterization in the novels. Therefore, the novelist defends the cohesive identities of the characters with their optimistic attitude towards a better life to live.

The research information in supporting of this research paper have been collected from the different sources. The primary sources are the of reading Hardy's selected novels deeply, and the watching movies on his novels carefully. The secondary sources are the study materials from the substitute books and research papers from the print and e-journals, and web link access. Other sources are the suitable suggestions and scientific discussions with the research co-author, professors, colleagues, friends, and my own research experience. 


\section{RESEARCH OBJECTIVES}

Hardy's novels after Dickens' novels stood up on the emerging tools of serialization, industrialization, economic development, class-clash, science versus religion, progress of ordinary class, allegorical views, nostalgia, woman laws, and utilitarianism. It was largely characterized by the psychological struggle of working people and the triumph of wrong over right. So, a keen insight and detailed study have been done to get the both mental situations of the characters in the novels of Thomas Hardy to prove the role of optimism over pessimism in the novels of Thomas Hardy to its mechanism of fate and chance.

Therefore, this article leads to the new contributions to the existing knowledge of the groundwork research by which it is possible to make progress in the field of exploration that investigates the indeed questions to explain with scientific facts and developed thoughts that what are theories of optimism and pessimism? What is the role of optimism and pessimism to create the atmosphere of action flow in the plots? How does the theory of accidentalism work for its mechanism to punish the characters in the novels of Thomas Hardy? How does optimistic attitude run in the psychoanalytic and eccentric impulses of the characters? In which manner optimism is strong over the pessimistic attitude? How are metaphorical conversations being used in his fiction? All these mentioned questions are scientifically being analyzed and discussed with the facts, supporting views, and developed thoughts fruitfully in the support of this paper's title.

\section{REVIEW OF LITERATURE}

Hardy's inspirational resources developed his ethical and philosophical views under the deeply rooted study of the works of the Old Testament, Shakespeare, Greek writers, Charles Darwin, Thomas Huxley, Charles Fourier, Hippolyte Taine, Auguste Comte, Huxley, Spencer, J. S. Mill, Thomas Carlyle, Walter Pater, John Ruskin, Robert Browning, Matthew Arnold, George Eliot, and Charles Dickens mostly.

Hardy liked too much the myths, allusions, and the concept of the divine creation of man in the Old Testament with its simplicity and intellectual dexterity; but he did not find the solutions for the hardness and hurdles of human lives. Faith in religion could not offer help for the human sufferings. Therefore, Hardy had lost faith in the religion at the middle of age under the influence of Darwin's The Origin of Species. But Hardy had complex attitude with the practices of the institutional Church that establishes human's original values among the societies, as he was quoted by Edmund Blunden to say: "If there is no church in a country village, there is nothing".

Therefore, Hardy is an agnostic and castigator of the religion; but even about 600 biblical allusions are found in his all literary works; from which around sixty allusions had been quoted in his novels, Far From the Madding Crowd, The Return of the Native, Jude the Obscure, and Tess of the d'Urbervilles. As he wrote later,

\section{I have been looking for God for fifty years and think that if he had existed I should have discovered him.}

(Duffin, p.196)

Finally, Hardy came to know that religion plays a role only that misleads and deludes various characters of a man which cause his final fall. Hardy was the first truly urban novelist who anticipates the themes and language of twentieth century fiction. He captured the vitality of life and also the deprivation of Wessex. Victorian novels tended to be idealized 
portraits of difficult lives in which hard work, perseverance, love and luck won out in the end coincidently. The characters were usually inclined towards being of improving nature with a central moral lesson at their heart that pushed them towards the optimistic attitudes.

\section{MECHANISM OF CHANCE AND FATE RESULTED IN PESSIMISM}

All the main female characters are decorated with like the goosey gracious looks and figures that appeal to create the excitement of seductive sex intercourse and lustful impulses to the male characters in almost all the novels of Thomas Hardy. Therefore, the characters are elevated in the stern religion of seductive lust. They are disciplined unsympathetically for their sexual impulses. As a result, the feeling brain emerges and dominates over their eccentric-psychology that does not feel well because of their emotional suffering and suppression. Their feeling brain identify that the sex is wrong. But other hand, the thinking brain elongates the worked out that sex is accepted, ordinary and entirely awesome. Therefore, their emotions and excitement oscillate between feelings of superiority and inferiority, and psycho-analytical conditions to which Hardy has Hellenic and pagan sympathies. So, either all male-female characters must have to be loved or hated by each other on the privileged path of interest or detachment in their caricatures. Sometimes an event might be either the best moment of their lives or traumatizing. Such circumstances of high and low self-worth appear differently on the surface, but they are two sides of the same counterfeit coin. Because whether they feel as though they are better than the rest of the world or worse than the rest of the world, the same thing is true, they are imagining themselves as something special, something separate from the world.

Hence the feeling mind soars in search of comfortable emotions and impulses that come from the addictive mental forum and state. For instance, a man cannot quit smoking, drinking wine, over dieting and other bad habits in his real life. Why? Because he is not comfortable without doing and having all these silly and the same things in order to feel better.

So, the characters follow to the different ways for a perfect life in the fabricated plots of Hardy; but, where their lives begin only for a pessimistic journey of pain and sorrow. Their identities sound a toxic social status that crystallizes a sediment on the top of their doubled standard personalities and performances of the obnoxious colors of their lives. Thus, they only gained all the pains from the far hope, that they could never get rid of, which stables a universal constant of the human conditioned currency to pay for surviving the uncomfortable truth of a worst life.

The emotions of the characters are badly being sorted, enslaved, tortured, and suppressed in every plot. Their appearances justify their abused and subjugated presence. But Hardy kept his protagonists alive to survive for a ray of hope into their monotonous hearts that is like a day-dream that never comes true. This may be a hard truth to understand deeply rooted for the common readers. But the ray of optimism moves on the flow of feeling brains of the characters in the plots. The thinking brains of the readers find the characters which are trapped into the deep and dense swamp and mud of the psychological depression, disparity, emotional frustration on the exaggerating facts of the ethnographic community and culture that never sounded nice and noble to their survival.

Pessimism is a negative thinking in which a character frequently identifies opposite or negative aspects of the situation rather than vibrating towards the going right aspect. A character suffers a lot from the depressed mental attitude and undesirable outcomes that effect on all major areas of his thinking negatively. Therefore, a character feels everything negative around himself that affects also other characters over there. The elements and emotions of pessimism emerge from the mechanism by the accidents. When things happen sadly suddenly in the character's life and after that, he is tortured and beaten through the 
chance, fate, nature's mishaps, and untimed attempts. This procedure is identified as a theory of accidentalism that plays the role of a machine that functions non-stop pathetically according to the programming.

The inspirational resources of Hardy's pessimism are from the popular Calvinism, Darwin's theory of natural selection, Schopenhauer's philosophy, and traditional folk fatalism. Lives of his characters had been controlled by fate, chance of time, blind forces of nature, laws of civilization, heredity and environment to suffer extremely that filled them with the pessimistic impulses. Such tragic phenomenal attitude emerged due to the loneliness of the individual in dehumanized society which the characters had lost their touch with timeless and organic order to accepting the inevitability of suffering and evil which lies in individual relative virtue to their human existence. Therefore, his characters struggled to live with dignity and a sense of perennial values; but all goes in vain at last. Therefore, his pessimism is above the practical philosophy that declares itself an evolutionary meliorist. His pessimistic views came from the philosophy of determinism in that a man's life is controlled by some inexplicable external force, which he sometimes calls the fate of circumstances in The Mayor of Casterbridge, the president of immortals in Tess of the d'Urbervilles, and the immanent will in The Dynasts. Therefore, a man is determined by both heredity and environment.

Hardy has an existential point of view to his characters for their human condition, personal freedom and determinism, the attitude to God and religion, the role of destiny, failed human relationships and the alienation of human beings in the Victorian world.

\section{EFFECTIVE RADIATED POWER OF OPTIMISM}

Hardy also depicts in his novels that man has the capability and strength through which he can lead a life better and brighter, that is the basis of optimism. This capability of a human being provides him the power of possession and administration in the society. Hardy has shown in his novels through the struggling characters that they have power which would inspire them perpetually to go forward in achieving their goals in their lives. This strong 'will' to go forward and to progress leads a man towards hope and success. Continuity in success makes a man an optimist. In this context, Southerington rightly remarks:

\section{A major burden of Hardy's works up to the time of Woodlanders had been that man possesses adaptability in the face of his environment. This is why his works are fundamentally mechanist in their outlook.}

(F.R. Southerington, 1971, p.95)

Undoubtedly, Hardy wished the earth to be heaven. Life was not a tale of tears and a dale of dangers for him. In the novel, A Laodicean, he remarked that human nature is at bottom romantic. May be Hardy hoped for a perfect world, in a sense, less suffering and more joy. His lovers expect their sweethearts to be paragons of virtues. Angel Clare's love was 'ethereal to a fault, imaginative to impracticability'; Egbert Mayre's love was worship of Geraldine, Smith idealized Elfride, so did Knight; Dick Dewey idealized Fancy Day. Elfride said to Stephen Smith, "It appears that men want to make the world to suit their happiness". They are not happy with things as they are looking for perfection. This tendency can be seen in the other novels of Hardy as well. Somerset in A Laodicean and Clym Yeobright in The Return of the Native are good examples of this tendency. In this connection, H.C. Webster aptly explains: 
Hardy wished to think out all the metaphysical implications of his newly assimilated knowledge. He wished, if possible, to find some positive counterpart to these negative conclusions, a certainty, a positive faith which would enable him to believe in the eventual amelioration of things.

(H. C. Webster, p.72)

Hardy was deeply impressed by the optimists of his Age, that is why he observed things minutely and after that he searched a way to hopeful life. He realized like the Indian philosophers that the world is full of sorrows and sufferings but by adopting a proper way one can go out of it and lead the life of hope and happiness. In this context, the following view adheres:

Hardy was familiar with optimistic and idealistic faith; that is why the poem of Wordsworth appealed to him most. His amelioration for Carlyle made him list his essays as accrue for despair ... Hardy must have been familiar with the writings of the optimistic thinkers of his age.

(T.M.J. Indra Mohan, 1990, p.268)

\section{MECHANISM OF OPTIMISM OVER PERSSIMSM}

In Hardy's universe, evils fail, and accidents intervene to make a happy marriage out of unhappy one. Chance can be responsible for happiness. But he never felt that the world is in a hopeless state. In fact, inspired by the robust optimism of the most of his contemporaries, he believed in the progress of mankind. To bring home this point, Hardy wrote on 29 April, 1867:

Had the teachings of experience grown cumulatively with the age of the world, we should have been here now as great as God.

(Florence Emily Hardy, 1962, p.55)

This shows that Hardy believed in the slow progress of humanity. He believed hopefully that with the passage of time the world will enrich mankind with hope, health and happiness. Such hopeful intentions represent the optimism of the novelist. Hardy's optimism can be seen through the characters of his novels, which are mostly his mouthpieces. Their actions and attitudes are endowed with hope and joy. In this context, Webster's view is remarkable:

Although his (Hardy's) optimism about the laws which govern the world and man has, for the most part, failed him, his optimistic view of most men and women continued.

(H.C. Webster, p.72) 
On the basis of the above observation, it can be said that Hardy's optimism regarding human society would be continued and in this way his optimistic views would provide a new way of life for the people who are unable to realize and notice the beauty and pleasure of the world. In the world where men and women have optimistic views, there will be brotherhood of men and fatherhood of God. Hardy was not sad and sorrowful throughout in his novels. His novels are full of hope and pleasure as several pleasant situations can be seen in his fiction, and as he is known for:

\begin{abstract}
describing exquisitely: the feast in Far From the Madding Crowd; the enchanting gaiety around the bonfire in The Return of the Native; the Christmas evening with the murmurs, and the dance at Tinker Dewey's Inn in Under the Greenwood Tree, are some examples to show his love for pleasure.
\end{abstract}

(T.M.J. Indra Mohan, p.261)

\title{
8.HARDY'S OPTIMISTIC CHARACTERS
}

Thomas Hardy's pleasant presentation of his characters in his novels show that he has an optimistic attitude towards life; that is why his characters represent his view. In any literary creation characters are the mouthpieces of the writer and they have similarity in views with the writer. Having such philosophical and religious views and visions, a novelist cannot be a pessimist but he is an optimist.

Hardy believed that human nature has much that is good in it and hence there is a hope for amelioration of mankind in this world. His writings reveal a desire to make the world better and brighter as Webster puts it:

It one regards a wish to thoroughly change society as an indication of optimism, one might make out a very good case for Hardy's having been, when he wrote The Poor Man and the Lady, considerably more sanguine than most of his contemporaries.

(Webster, p.72)

In his first unpublished novel, he had optimistic intentions and inclinations and after that this view was manifestly presented in his other novels; Hardy being an optimistic novelist, wanted to remove the evils of society so that people might live and lead a lovely life. For this very reason, he advised through the activities of his characters that one should try to stand in a stormy night as the day is surely to come out; in the same way, after pain, pleasure comes. The characters in the novels of Thomas Hardy show that they are endowed with optimistic intentions. His intention was to provide a positive way for people of the society. Hardy was not an expounder and exponent of a negative philosophy which was based on illusions. Hence, he did not believe in pessimistic determination either. In this context, Howard Baker rightly remarks:

His (Hardy's) philosophy is concrete, rough and workable; it has a few more than ordinary limitations; it has somewhat 
more than ordinary powers because of its rude honesty. It is richly and rightly human.

(Howard Baker, p.57)

The above statement leads to the philosophic thought of Hardy towards humane approaches of life. In the society 'it is natural for a man to have a humane approach because he has to live peacefully and pleasantly in the humane society. In this way, we can say that through the understanding of human nature properly, a man can lead a hopeful and joyful life. In the novels of Hardy, it can be seen that his characters are the determiners and deciders of their own destiny. Their optimistic pragmatism leads them towards success and pleasures of life. In this connection, F.B. Pinion aptly comments:

It is a timely reminder that chance is not the sole determining factor in course of Hardy's stories, and that character is an important element in the evolutions of destiny.

(F.B. Pinion, p.24)

The above comment makes us realize that creation of characters indicates the purposefulness of the novelist. Hardy has created these characters with optimistic intentions and inclinations. That is why they struggle hard for their entity and dignity. They, as some critics think, are not puppets or toys in the hands of God rather than they participate in the walk of life in the society and in the world.

Thomas Hardy tries his best to show through his male and female characters that in this world, situations and circumstances can be changed from time to time to some extent. Everybody who makes efforts to get better results in life gets them accordingly with the passage of time. In his efforts, there should be hopefulness and faith so that he or she may maintain the continuity of his proper action. Without realization of hard and harsh things in life, no one can get its solution in easier form. H.C. Webster is also of the same view:

Hardy does not see such a universe as utterly meaningless. He wants to show us the sorry condition of man in this world and make us realize that there are some 'irremediable ills' and that there is at least a limited opportunity for happiness.

(H.C. Webster, p.105)

\section{FACTS AND ELEMENTS OF THE OPTIMISM IN HIS NOVELS}

Some novels of Hardy are explicitly optimistic. For instance, his novel, Far From the Madding Crowd, has been classified under the heading of the "Novels of Achievement", as T.M.J. Indra Mohan observes:

In this novel, (FFMC), both the hero and the heroine have overcome their misfortune. This ending is happy only if one ignores the suffering that precedes it. 
(T.M.J. Indra Mohan, p.276)

The novel, no doubt, is optimistic as it has a pleasant ending. In this novel, we see that having full faith and bright hope; the protagonist Gabriel Oak becomes gloriously victorious in the end in his longing for the heroine, Bathsheba's love. About Hardy's optimism, in consonance with the novel, the critic Webster is of the view:

the book as a whole cannot be called unrelievedly pessimistic even if one accepts the author's protest against Fanny's treatment by society. At the end of the book the two most admirable characters finally marry.

(Webster, III)

The novel, Far From the Madding Crowd, Gabriel Oak, the hero of the novel, achieves what he desires as he struggles a lot for it. The novel has a tinge and touch of hope in future as the critic Indra Mohan also observes:

Though Bathsheba, Boldwood, Fanny and Troy submit rather passively to circumstances, Oak never submits himself to it. He is the first of Hardy's characters to succeed by resisting fate ... Although initially he does not win Bathsheba, his persistence eventually succeeds. He is ambitious. Whatever may be the setbacks, he is hopeful of his attainment by his persistent diligence. His struggle with fortune is an equal battle, which ultimately yields to him.

(Indra Mohan, p.278)

On the basis of the above observation, it can be said that the novel adheres to Hardy's optimistic philosophy as the hero of the novel; Gabriel Oak wins in the end in the battle of love and life. Thomas Hardy has presented his characters in an optimistic way in his novels. He presents the worst situation even though he suggests that hope should be expected regularly. Southerington is right when he says,

Hardy first attempt to take a full look at the worst" in the hope that amelioration might come that way.

(Southerington, p.91)

This statement justifies the view of the novelist as he inspires the readers that everybody should be ready to face the obstacles and impediments in the journey of life. In this way, Thomas Hardy participates in the creation of pleasant human society where people could be ready to go forward even in unfavorable situations and circumstances. This trust and will to humanity leads a man towards an optimistic approach to life.

The novel, The Trumpet Major, depicts the restoration of things past. The roving Bob Loveday in The Trumpet Major is something of a nineteenth century Odysseus. He returns to 
marry to his boyhood sweetheart and to live happily on his nature isle after a heroic role in the Napoleonic struggle. The novel, The Trumpet Major, shows optimism of the writer. What struck him most was the standard in this novel. He himself called it a "cheerful story" and was intended to "wind up happily". This optimistic approach of Hardy has been aptly supported by Richard H. Taylor as he is of the view:

The Trumpet Major is a novel of moderation; no issue is forced, and human nature is subjected to no extremities of behavior ... The lack of any philosophizing is conspicuous, but the absence of formulated ideas does not necessarily imply a lack of serious purpose ... In The Trumpet Major, overt philosophizing reflections are eschewed in favour of a straightforwardly descriptive narrative bearing only the occasional moral aphorism. Again this would satisfy readers who did not wish to be implicitly harangued about the in adequacies of their religious systems and who would shy away from Hardy's alleged pessimism.

(Richard H. Taylor, pp.82-83)

In another novel, A Laodicean (1881), Miss Paula has love for both Somerset and De Stancy and ultimately she married Somerset. The novel shows that Hardy has optimistic view of life, which has shown such hopeful steps in the novel. In this connection, Webster observes:

It seems as though Hardy's meliorism, which was so mutual as to be scarcely evident in The Return of the Nature, is increasing in intensity again.

(Webster, p.142)

Thomas Hardy himself intended to show hopefulness in the novel, A Laodicean. He wrote about it in his Wessex edition of the novel that:

A Laodicean may perhaps help to while away an idle afternoon of the comfortable ones whose lives have fallen to them in pleasant places; above all, of that large and happy section of the reading public which has not yet reached ripeness of years.

(Orel Harold, pp.15-16)

This shows that Hardy's novel, A Laodicean, is not only optimistic but it is pleasant also for the readers of the society. In this way, the novelist provides hope and pleasure both to the people who study his novels. 
In the novel, Two on a Tower (1882), humane approaches of life have been presented. Christianity has also been presented in a religious touch, tone and tinge. About this optimistic approach, Peter J. Casargrande rightly remarks:

Luck and unusual capacity for self-sacrifice enable Viviette to the Smithin's redeemer, and make two on a Tower Hardy's happiest, and last vindication of humanist credo.

(Peter J. Casargrande, p.183)

On the basis of the above statement, it can be said that the novel, Two on a Tower does not show only the optimism of the characters; more than this it shows that the characters have patience and they sacrifice for the sake of hope and pleasure. These characters prove Hardy's optimistic views as they are created and endowed with hope and happiness.

In the novel, The Mayor of Casterbridge, Hardy's optimism has been presented through the foil character of Donald Farfrae who succeeds in life to have hope and faith. He tries hard to get success even in the unfavorable situations of life, as a critic clearly comments:

He (Farfrae) is cast as the agent of renewal and hope is the ingenerate world of the novel. He has knowledge to restore the almost completely blighted wheat. He works to rehabilitate Henchard's fall from prosperity, offers a sound chance and a new life to Lucetta and rescues Elizabeth Jane from loneliness and neglect.

(Santosh Chakrabarti, p.125)

Hardy's philosophy of life was neither pessimistic nor tragic but it was amelioration and optimistic as a critic says:

Hardy always had hoped for - one might even say had faith in - the possibility of ultimate amelioration, in all his novels, to a degree which fluctuates with both the circumstances of his life and the spirit of his times, he shows his belief in the possibility of social change by his protests against man's inhumanity to man - This belief which he does not seem fully conscious of himself, which he was not able to reconcile with the rest of his systems until he wrote The Dynasts, is important even in those novels which are otherwise most strongly pessimistic and deterministic ... For Hardy's social protests are based upon a hope for ultimate amelioration.

(H. C. Webster, p.171)

The above statement of Webster shows Hardy's belief in the changing of the social systems. He depicts in his novels that by adopting humane approaches towards man and society, one can change the social ethos with the passage of time. He believes that betterment 
and advancement in life can be possible even at the last stage. That is why he has always hoped for future goodness.

In the novel, Jude the Obscure, Jude was sufficiently profited by his suffering to see a hope of a new start, free of everything except faith in and fidelity to human needs and basic values. About this optimistic aspect of Hardy, the critic Peter J. Casagrande of the view:

What remains to affirm the life and endeavour of Jude and Sue Bridehead is the memory of their love, ennobled by its comparative freedom from physical grossness; this courageous assertion of Hellenic joy and meaning and human dignity against the abstraction of society and looming and glooming dark of death, their love and compassion for all living things, creatures bound to them in a common mystery of suffering. In the event, it is Jude's qualities that affirm this epic of modern existentialist man.

(Peter J. Casagrande, p.217)

The novel, Jude the Obscure, depicts optimistic approaches of Thomas Hardy as he reflects his ideas and ideals through the courageous character of Jude, who strives for advancement and betterment in the field of knowledge, love, hope and humanity. Hardy tried to reveal and reflect in his novels that in spite of sorrow and suffering, misery and misfortune in the world, there was a way out of it, if someone struggled hard to go out of it. In all probability, Hardy wanted to show that in this world, despite pain, evil and suffering, there was a possibility to better and brighter and make it happier by loving kindness and leading and living a sincere and successful life. In Hardy's novel, there is an intention of making life hopeful, good and healthy, as Irving Howe observes:

The doctrine of the Immanent will or the Purblind Doomster allowed him to express a mild hopefulness, what he called "meliorism" with regard to the ultimate destiny of the race.

(Irving Howe, p.26)

\section{OPTIMISM : SPIRITUAL CONTENTMENT}

In the novels of Thomas Hardy, there is search not only for material goodness and pleasure which is physical rather there is also a yearning for the spiritual optimistic contentment that can be inherently realized by human being in the world. He believes in the inherent goodness of man. Hence, he refuses to give up hope in the voyage of life devoted to goodness and truth, even though it may not have any reward. He preaches that the innate goodness of man brings poise and peace - if not in terms of any material gain or reward per se. It is not pessimism but altruism; however, much the will may be powerful, as Elliot also opines:

is resignation, devotion to Beauty, Truth and Goodness ... we

can live by a code of morality superior to that of the will. 
(Albert Pettingrew Elliot, p.108)

Thomas Hardy's major fictions are endowed with the aspects of optimism and satisfaction as a critic comments:

By 'Fulfilling' the promise of the beginnings, the endings imply that the world in which men live is closed and invulnerable to essential change. The title of Tess last phase, "Fulfillment", implies, he thinks, something about Hardy's World view and aesthetics. By fulfillment, he means the inevitable bringing to fruition of the pattern that derives from the interaction of the central character's psyche with the world in which he (or she) is placed. After Far From the Madding Crowd, the endings fulfill the prophecies of the opening chapters.

(Daniel R. Schwarz, p.18)

This shows that Hardy's protagonists are satisfied and that is why they are optimistic about their future life. Such optimistic psyches of the characters represent the optimism of the novelist.

In the novel, Tess of D'urbervilles (1891), Hardy shows that Tess was able to get hope and pleasure it does not matter its short span of time. In the words of a critic, it can be said:

The final phase of Tess of D'urbevilles is entitled "Fulfillment" to describe Tess' relationship with Angel. The ephemeral nature of that relationship shows that man does indeed live on blighted star and fulfills the expectations around by the novel's opening.

(Ibid, p.30)

The above view supports that Hardy shows that his protagonists of the novels are able to satisfy their faithful intentions as they struggle and strive for it. Here lies the effort which brings hope and fulfillment. Hardy's protagonists of his novels have the power of endurance. That is why they are able to face the obstacles. Such optimistic insight of Hardy is observed by Virginia Woolf, one of Hardy's earliest feminist critics. She said:

"Tragic power" of his characters to a "force within them" which cannot be defined, a force of love or of hate, a force which in the men is the cause of rebellion against life, and in the women implies an illimitable capacity for suffering.

(Virginia Woolf, p.253)

The feminist critic is quite close to the view of Hardy as he believes that people have power to struggle with the obstacles of life. In this context, it can be said that capabilities of 
men and women empower them with optimistic visions and views. About the pure woman (Tess) and especially those who have optimist views about marriage, it can be said that they are hopeful about marriage, as the critic says the same thing:

One finds major female characters such as Cytherea Graye, Fancy Day, Elfride Swancourt, Bathsheba Everdene, Ethelberta and Picotee Chickerel, Thomasin Yeoright, Anne Garland, Paula Power, Elizabeth Jone, Marty South and Grace Melbury - all of them the heroines of one of the novels. With the exception of Mary South and Grace Mebury, all may be thought to find eventually a measure of happiness in marriage. One recalls that Bathsheba, quite practically, need Gabriel Oak.

(Leon Waldoff, p.145)

All these characters had a happy and hopeful married life that depicted the optimism of the novelist who had created such situations for the characters. Marriage is a moment of someone's happy life as a critic says,

Hardy asserted in so many words that tragedy always underlies comedy.

$$
\text { (H.C. Duffin, p.250) }
$$

As we have already said that Thomas Hardy was not a pessimist as he was a meliorist who wanted to evolve new hope and pleasure, as H.C. Duffin is also of the same view:

It has been observed, at the end of The Mayor of Casterbridge, Hardy allowed himself to be betrayed in to taking note of a fact which, if not joyful enough to called optimistic, has a least on anti-pessimistic tinge about it. He made Elizabeth Jane "wonder at the persistence of the unforeseen" which had brought her to "unbroken tranquility", although her youth "had seemed to teach that happiness was but the occasional episode in a general drama of pain". Few enough of Hardy's characters find the "unforeseen" turning out. In this way Bathsheba and Gabriel Oak are perhaps the only others ...... This is in some ways the most hopeful word Hardy has pronounced if one can shut his ears to the discrepant word he said in Sue. Indeed, no writer who presents human kind so worthily can be a thought going pessimist. Your true pessimist is he who, like Swift, depicts man himself as degraded, contemptible. From Hardy's dark canvas there stand out the heroic forms of a mighty Adam and a beauteous Eve. With him 
man's far from god-voice, but still a moral being, rich in interest and of high capacity.

(H.C. Duffin, pp.254-255)

Both of these aspects, optimism and pessimism are not permanent. In general walk of life, it can be seen and realized that pessimistic outlook is traditional. In this context, Hardy speaks in Tess of the d'Urbervilles, "the chronic melancholy which is taking hold of the civil is of races with the decline of belief in a beneficent power". At the moment that "melancholy" appears to be in process of being replaced by certain irresponsibility:

This is an equivocal substitution, but is perhaps a necessary step towards the enthronement of a steadier joy and a wider hope that will come when the faith of the future takes hold upon human consciousness. Thus, it can be said that Hardy's meliorism included some conception of this new faith is apparent from his poetry...

$$
\text { (H.C. Duffin, p.256) }
$$

One gets from Hardy what one gets from any good novelist, a knowledge of life and the way how to face the vicissitudes of life:

if the stuff of human nature is as good as this, education, culture, civilization ought to be able to make something of it.

(H.C. Duffin, p.259)

However, we can learn from the Wessex novels that there are worth to the ideal living upto betterment among the community of struggling characters for the challenged aims of the characters' lives. Therefore, a sincere, scientific, and concise attempt has been made in this article that the mechanism of accidentalism proves the existence of the characters in his novels is strong optimism that keeps them alive happy over the pessimistic struggles till to gain aims of the life. Thus, the results of this scientific research focused on a change in the philosophical views of the research problems which extended far beyond the restricted domain of scientific and ideological analysis.

\section{CONCLUSION}

A piece of literary work is produced by a writer for the creation of the thematic views, ideology of thoughts, perspectives of philosophy, and psychoanalytical presentations. In his or her work, a writer speaks through the views of his characters as they are the mouthpieces of the writer. In the case of Thomas Hardy, there would have been pessimistic characters in his novels and they would have been full of frustration, depression and dejection. On the contrary, it can be seen that his characters represent his optimistic and hopeful views. In the heart of Hardy's finest characters there burns and glows a light and that light is never allowed to be grown dim and dwindle. Remember Oak and his probity, Clym Yeobright and his altruistic schemes, John Loveday and his self-renunciation, Gles 
Winterborne and his chivalrous consideration, Marty and her unchanging and everlasting love, Tess and her fidelity and faithfulness, Jude and his undying dream, and Sue Bridehead and her dream too. Of Hardy's treatment of love, something has been said, but of its beauty as an ideal he speaks through the shining figures of the four faithful men, and of Marty, and of Tess, and of Jude and Sue. Thus, it can be concluded that Thomas Hardy's philosophy of life is pessimistic as well as optimistic at least in the portrayal and presentation of the characters. But in this article, it has been presented and proved that Thomas Hardy is among those novelists of the Victorian age, who glorifies the optimistic views over pessimism of the Wessex common folk of his surroundings. Consequently, his importance lies in the fact that he represents the laymen and their ambitions and aspirations, hopes and expectations positively, fully and faithfully.

In this way, this analyzes the scientific discourse and systematic outputs after reading his novels thoroughly and thoughtfully that Hardy is a strong optimist stayed till the last in the ideology, philosophy, psychology, and cohesive identities in the characterization. Optimistic element keeps alive the characters happy and hopeful for a life full of pleasures over the pessimistic flow. Pessimistic element emerges from the mechanism by an instant accidentalism of chance, fate, nature's mishaps, and untimed attempts. Therefore, his characters in the novels struggle and strive, hope and expect and they depict their optimism over pessimism.

\section{REFERENCES}

Elliot, A. P. (1966) Fatalism in the Works of Thomas Hardy, New York: Russell.

Hornby, A. S. (2000) The Oxford English Dictionary, Ed. Sally Wehmeier, New York: Oxford University Press.

Schwarz, D. R. (1989) Beginnings and Endings in Hardy's Major Fiction, Critical Approaches to the Fiction of Thomas Hardy, Ed. Dale Kumar, London: Macmillan.

Hardy, F. E. (1962) ed. Life of Thomas Hardy, London: Macmillan

Southerington, F. R. (1981) Chapter II, Hardy's Vision of Man, London: Chatto.

Pinion, F.B. (1968) A Hardy Companion, New York: Macmillan.

Orel, Harold (1977) ed. Hardy: Personal Writings, London: Macmillan.

Webster, H. C. (1984) Chapter III, On A Darkling Plain: The Art and Thought of Thomas Hardy, New York University of Chicago Press.

Duffin, H. C. (1993) Thomas Hardy: A Study of the Wessex Novels, Delhi: Doaba.

Baker, H. (1940) Hardy's Certitude; The Southern Review, Vol 6, Summer: No.1.

Howa, I. (1978) Thomas Hardy, London: Widonfield \& Nichalson.

Waldoff, L. (1989) Psychological Determinism in Tess, Critical Approaches to the Fiction of Thomas Hardy, Ed. Dale Kumar, London: Macmillan.

Casagrande, P. J. (1992) Unity in Hardy's Novels, London: Macmillan.

Taylor, R. H. (1972) The Neglected Hardy, London: Macmillan. 
Chakrabarti, S. (2001) Hardy's Woman: A Feminist view, Thomas Hardy: A Critical Spectrum, Ed Rama Kundu, New Delhi, Atlantic.

Indra M, T.M.J. (2001) Thomas Hardy's Life and Works: An Overview, Thomas Hardy: A Critical Spectrum Ed. Rama Kundu, New Delhi: Atlantic.

Woolf, V. (1932) The Novels of Thomas Hardy, The Common Reader, Second Series, London: Hogarth. Retrieved from: www.victorianweb.org)authors hardy diniejko3 